\title{
Application of various forms of physical education as a factor of increase in the level of physical activity of medical students
}

\author{
Osipov A.Yu. ${ }^{1,2,5 \mathrm{ABCDE}}$, Kudryavtsev M.D. ${ }^{1,3,4,5 \mathrm{ABCDE}}$, Markov K.K. ${ }^{6 \mathrm{BCDE}}$, Kuzmin V.A. ${ }^{1 \mathrm{BCDE}}$, Nikolaeva O.O. ${ }^{1 \mathrm{ABD}}$, Zemba \\ E. A. ${ }^{3 \mathrm{ABD}}$, Yanova M.G. ${ }^{4 \mathrm{BCDE}}$ \\ ${ }^{1}$ Department of Physical Culture, Department of Valeology, Department of Theory and Methods of Sports Disciplines, \\ Siberian Federal University, Russia \\ ${ }^{2}$ Department of Physical Culture, Professor V.F. Voino-Yasenetsky Krasnoyarsk State Medical University, Russia \\ ${ }^{3}$ Department of Physical Education, Reshetnev Siberian State University of Science and Technology, Russia \\ ${ }^{4}$ Department of Theoretical Foundations of Physical Education, Krasnoyarsk State Pedagogical University of V.P. \\ Astafyev, Russia \\ ${ }^{5}$ Department of Physical Training, The Siberian Law Institute of the Ministry of Internal Affair of Russia, Russia \\ ${ }^{6}$ Department of Physical Culture, Irkutsk National Research Technical University, Russia
}

Authors' Contribution: A - Study design; B - Data collection; C - Statistical analysis; D - Manuscript Preparation; E - Funds Collection.

\begin{abstract}
Purpose: $\quad$ increase in the level of weekly physical activity of medical students of HEI by application of various forms of physical education training.

Material: $\quad$ Senior students participated in a research $(n=78$ - males, $n=190-$ females, age $-21-23$ years). Indicators of physical strength development were estimated by the number of pull-ups on a horizontal bar (males) and by the number of floor push-ups (females). Development of speed was estimated by the time of cover $100 \mathrm{~m}$ a distance. Level of the general endurance of an organism was estimated by results of cover $3000 \mathrm{~m}$ a distance by male students and $2000 \mathrm{~m}$ by female students.

Results: $\quad$ it was revealed a significant increase in time of physical activity training in students of experimental groups. The average time of physical training was $3 \pm 0,08$ hours per a week. This indicator is significantly above $(P<0,01)$ than in students of control groups. Indicators of strength development, speed and general endurance in students of experimental groups is significantly above $(P<0,01)$. Body weight indicators significantly increased $(P<0,05)$ in $2,3 \pm 0,2 \mathrm{~kg}$ in students of control groups. Indicators of body weight slightly increased in $0,4 \pm 0,2 \mathrm{~kg}$ in students of experimental groups.

Conclusions: Various forms of physical education promote increase in the weekly level of physical activity of students.

Keywords: $\quad$ health, physical activity, students, medical, various, physical training, body weight.
\end{abstract}

\section{Introduction}

Health care experts confirm that the lack of physical activity is one of the leading risk factors of global mortality. It is revealed the significant decrease in the level of daily physical activity of the population [1] in the countries with the high standard of living and in developing countries [2]. The decrease in physical activity is caused by the spread of noninfectious diseases in the majority of the countries in the world. These diseases have essential connection with a personal way of life and with a lack of physical training and motor actions in daily activity [3]. The essential lack of physical activity is observed in students of medical higher education institutes. More than a half of medical students in Thailand have no sufficient level of physical activity during a day. The decrease in the level of physical activity of future doctors is connected with intensive educational activity and overtime work in hospitals [4]. According to the experts' opinion, there is a strong connection between the personal level of physical activity and success of medical practice [5]. Also, there are data concerning a positive connection between the regular physical activity of medical students and level of their academic achievements [6]. Thus, the lack of daily physical activity exerts a significantly negative impact on the level of physical health and professional readiness of

\footnotetext{
(C) Osipov A.Yu., Kudryavtsev M.D., Markov K.K., Kuzmin V.A., Nikolaeva O.O., Zemba E. A., Yanova M.G., 2018 doi:10.15561/20755279.2018.0305
}

future doctors. It is necessary to recognize that the problem of physical activity lack is relevant not only for medical students. Researches devoted to the physical activity level of USA colleges' students demonstrated that from 40 till $50 \%$ of young people has essential lack of daily physical activity [7].

The development of obesity in young people [8] during the study at the higher education institutions is also a serious problem [9]. This problem is distinctive of medical students. The researches of G. El-Kassas demonstrated that about a third of medical university students of Lebanon have overweight and obesity [11]. Experts confirm that young people nowadays don't pay attention to the daily physical exercises $[10,12]$ and have sedentary lifestyle [13] in front of TV and computers [14]. It is revealed the lack of daily physical activity in a significant number of students in South Korea. Unfortunately, most of Korean students don't consider physical training as the important part of a study, in comparison with study mathematics or medical sciences [14].

It is determined the need to develop and apply the specific programs for the increase in physical activity and the decrease in the sedentary lifestyle of students at the universities worldwide $[15,16]$. Special attention should be paid on normalization of nutrition and actions promoting the increase in physical activity in students. Performance of these tasks will allow to decrease significantly the future risk of emergence of various noninfectious diseases 
[17]. The normal body weight, the optimum mode of every day and daily physical activity [18] are the factors exerting a positive impact on the level of young people health [19]. The overweight of a body is a factor of negative influence on youth health [12]. Researches demonstrated that the operated intervention in the educational process allows to achieve significant changes in the culture of food and physical activity level of students [20]. According to S. Beni's opinion, the operated intervention in programs of physical training and youth sport has to be based on a social interaction of teachers and students and increase of positive emotions. It is also necessary to provide growth of positive emotions in students of physical exercises and sport [21].

Researches demonstrate that the main motives for sports activities and physical training for modern students are: the growth of popularity among other students of higher education institution, the social status and physical appeal [22]. The motivation plays a crucial role in the maintenance of physical activity [2]. Therefore, it is necessary to maintain the motivation of young people at the high level for increase the physical activity of students. Achievement of the high level of students' motivations is possible only by the transition from obligatory programs of physical education of youth to individual and personal programs of physical development of student's youth [23]. It is known that in some countries educational programs devoted to the physical training of youth significantly change the orientation from sports improvement to fitness [24]. In China, the government accepted the national strategy providing participation of the population in physical activity not less than 30 minutes 3 times a week [25]. It is known that obligatory physical training classes are carried out only 2 times a week. Therefore, it is necessary to motivate and stimulate young people to regular independent training in a free time. Unfortunately, in many countries, educational institutions and teachers of physical training don't see the need for changes in the existing standards of physical training of youth. So, in Greece, a lot of physical culture teachers prefer to apply the authoritative and completely regulated style of training. Teachers don't consider an initiative and a needs of students [26].

Students with sufficient free time for physical training don't reach the recommended daily volume of physical activity - 30 minutes and more a day [27]. Changes in programs of physical training in students are necessary: a significant increase in the volume of physical activity. Among such changes, experts consider the possibility of the choice by young people the various forms and types of physical training in convenient time [28].

Hypothesis. Authors presupposed that providing the choice of a various option of physical activity to medical students in convenient time will promote an essential increase in the level of their daily physical activity. The variability meant a possibility to choose the most attractive a type of physical activity.

The purpose of the research. Increase in level of weekly physical activity of medical universities students by application of various forms of physical training classes in the educational process

\section{Material and methods.}

Participants: The total number of examined people was 268 (males $-\mathrm{n}=78$, females $-\mathrm{n}=190$ ). All examined persons were students of senior (4-5) courses of Krasnoyarsk State Medical University named after Prof. V.F Voino-Yasenetsky. Age of examined persons was 21-23 years. All students had to attend physical culture classes not less than once a week. Such trainings are provided by curricula of future doctors. All students annually underwent medical inspection at the university clinic and had no contraindications to physical activity. Level of students' physical development at the beginning of the experiment wasn't significantly differed. All students gave the consent to participation in researches.

Organization of a research: Researches were conducted within an academic year. Students (males and females) were divided into equal groups: control - № 1 - males $(\mathrm{n}=39)$ and experimental - № 2 - males $(\mathrm{n}=39)$, control № 3 - females ( $\mathrm{n}=95$ ) and experimental - № 4 - females $(n=95)$. The students of control groups attended physical culture classes according to the educational schedule and the educational program. The students of experimental groups attended physical culture classes in the personal choice. It was allowed visits to the fitness centers, swimming pools, gyms, etc. At the same time, only students determined time of these visits, choosing the most convenient schedule. The indispensable condition was performance of temporary requirements to training - not less than 120 minutes per a week. All students submitted reporting documents: checks, bills, training plans. It allowed to determine precisely the time volume and intensity of physical activity on the various type of training.

At the beginning and at the end of the academic year all students hit a control qualifying standard allowing to estimate objectively their level of physical development. Indicators of physical strength development were estimated by the number of pull-ups on a horizontal bar (males) and by the number of floor push-ups (females). Development of speed was estimated by time of cover $100 \mathrm{~m}$ a distance. Level of the general endurance of an organism was estimated by results of cover $3000 \mathrm{~m}$ a distance by male students and $2000 \mathrm{~m}$ a distance by female students.

It was applied data concerning dynamics of body weight changes for estimation students' health level. Assessment of body weight indicators was performed by regular weighing. Authors didn't purposefully applicate different body weight indexes for assessment. According to the data of the last researches BMI indicators - Body Mass Index are exposed to considerable criticism of experts. Experts consider that BMI doesn't consider a correlation of muscular and body fat mass [29] and types of fat tissue distribution in organism [30].

Statistical analysis: The statistical analysis of control results was carried out by SPSS 20 program. The Student t-test was applied for checking results of average values in the connected samples. 


\section{Results}

At the beginning of researches the physical strength development indicators in male students weren't practically differed. Students of group №1 in the test of pull-ups on a horizontal bar performed $9 \pm 2$ pull-ups on average. Students of group №2 performed $9 \pm 3$ pull-ups on average. At the end of researches was revealed a significant difference $(\mathrm{P}<0,01)$ in the number of pull-ups in students of the experimental group. Students of group №1 performed $7 \pm 2$ pull-ups. Students of group №2 performed $10 \pm 3$ pull-ups on average. At the beginning of researches, female students didn't have significant differences in results of the test - floor push-ups. The number of pushups in students of the control group was $13 \pm 3$ push-ups on average. In students of the experimental group, the number of push-ups was $14 \pm 2$ on average. At the end of researches results of performance of this test were significantly differed $(\mathrm{P}<0,01)$ in students of the experimental group. Females from group №3 performed $12 \pm 3$ push-ups on average, and females from group №4 performed $16 \pm 3$ push-ups on average.

At the beginning of academic year indicators of speed development in male students of experimental and control groups weren't significantly differ. The average time of cover $100 \mathrm{~m}$ a distance by students of group №1 was $14 \pm 0,8 \mathrm{~s}$. Students of group №2 demonstrated $14 \pm 0,9 \mathrm{~s}$ on average. At the end of researches was revealed a significant difference $(\mathrm{P}<0,01)$ in indicators of cover time $100 \mathrm{~m}$ a distance by students of the experimental group. The average time of students of group №1 was $15 \pm 0,4$ s. Students of group №2 demonstrated $14 \pm 0,3$ s on average. Female students at the beginning of the researches had identical indicators of speed development. Average time in students of group №3 was $16 \pm 0,3$ s. Students of group №4 demonstrated $16 \pm 0,5 \mathrm{~s}$ on average. At the end of the academic year was revealed a significant difference $(\mathrm{P}<0,01)$ in indicators of cover time $100 \mathrm{~m}$ a distance in students of the experimental group. On average students of group №3 cover a distance in $17 \pm 0,8 \mathrm{~s}$, and students of group №4 in $15 \pm 0,9 \mathrm{~s}$.
At the beginning of researches the level of the general endurance development in students wasn't significantly differed. At the end of researches were revealed significant differences $(\mathrm{P}<0,01)$ in $2000 \mathrm{~m}$ run tests and $3000 \mathrm{~m}$ run in experimental groups. In males of group №1 results of this test were worse in $30 \mathrm{~s}$ on average. In males of group №2 results of cover $3000 \mathrm{~m}$ a distance improved in $38 \mathrm{~s}$ on average. In females of group №3 results of test run became worse in $37 \mathrm{~s}$ on average. Females of group №4 increased the results in this test in $44 \mathrm{~s}$. Thus, the difference between control and experimental groups in results of this test was more than 1 minute.

At the beginning of researches body weight indicators had no significant differences. In students of group №1 the average value of body weight was $86 \pm 0,7 \mathrm{~kg}$. In students of group №2 this indicator was $87 \pm 0,2 \mathrm{~kg}$. In females of group №3 the value of body weight was $65 \pm 0,6 \mathrm{~kg}$ on average. In students of group №4 this indicator was $66 \pm 0,4$ $\mathrm{kg}$. At the end of researches the average values of body weight indicators became significantly differ $(\mathrm{P}<0,05)$. It was revealed differences in groups of males and females. It was revealed the increase in body weight within 2,2-2,6 $\mathrm{kg}$ in males of the control group. Males from the experimental group didn't demonstrate significant differences in body weight indicators. It was revealed the increase in body weight in $1,8-2,2 \mathrm{~kg}$ on average in females of the control group. Female students of experimental group didn't demonstrate significant changes in body weight indicators. It should be noted that it was revealed dynamics of increase in body weight in all examined students. It can be explained by the natural process of growth of students' organism. Key indicators of students' tests are presented in table 1.

The volume of physical activity of students was considered according to the general time spent by young people for weekly physical activity. The track of time was carried out directly on physical culture classes. Also, students provided data concerning number and time of training in sports complexes and fitness clubs within every week of researches. At the beginning of researches data

Table 1. Indicators of physical development and physical fitness of students (males $-n=78$; females $-n=190$ ).

\begin{tabular}{|c|c|c|c|c|c|c|c|c|}
\hline \multirow{2}{*}{ Indicators } & \multicolumn{2}{|c|}{ Group №1 (n=39) } & \multicolumn{2}{|c|}{ Group №2 (n=39) } & \multicolumn{2}{|c|}{ Group №3 (n=95) } & \multicolumn{2}{|c|}{ Group №4 (n=95) } \\
\hline & b.r. & e.r. & b.r. & e.r. & b.r. & e.r. & b.r. & e.r. \\
\hline $\begin{array}{l}\text { Strength, } \\
\text { times }\end{array}$ & $9 \pm 2$ & $7 \pm 2$ & $9 \pm 3$ & $10 \pm 3$ & $13 \pm 3$ & $12 \pm 3$ & $14 \pm 2$ & $16 \pm 3$ \\
\hline Speed, s & $14 \pm 0,8$ & $15 \pm 0,4$ & $14 \pm 0,9$ & $14 \pm 0,3$ & $16 \pm 0,3$ & $17 \pm 0,8$ & $16 \pm 0,5$ & $15 \pm 0,9$ \\
\hline $\begin{array}{l}\text { Endurance, } \\
\min \end{array}$ & 14,22 & 14,58 & 14,20 & 13,42 & 12,35 & 13,12 & 12,32 & 11,48 \\
\hline $\begin{array}{l}\text { Volume of } \\
\text { physical } \\
\text { activity, min/ } \\
\text { week }\end{array}$ & $136 \pm 4$ & $134 \pm 5$ & $138 \pm 3$ & $182 \pm 4$ & $131 \pm 5$ & $132 \pm 4$ & $130 \pm 3$ & $176 \pm 4$ \\
\hline $\begin{array}{l}\text { Body weight, } \\
\text { kg }\end{array}$ & $86 \pm 0,7$ & $89 \pm 0,4$ & $87 \pm 0,2$ & $87 \pm 0,6$ & $65 \pm 0,6$ & $67 \pm 0,8$ & $66 \pm 0,4$ & $66 \pm 0,9$ \\
\hline
\end{tabular}

Note. b.r. - beginning of researches; e.r. - end of researches 


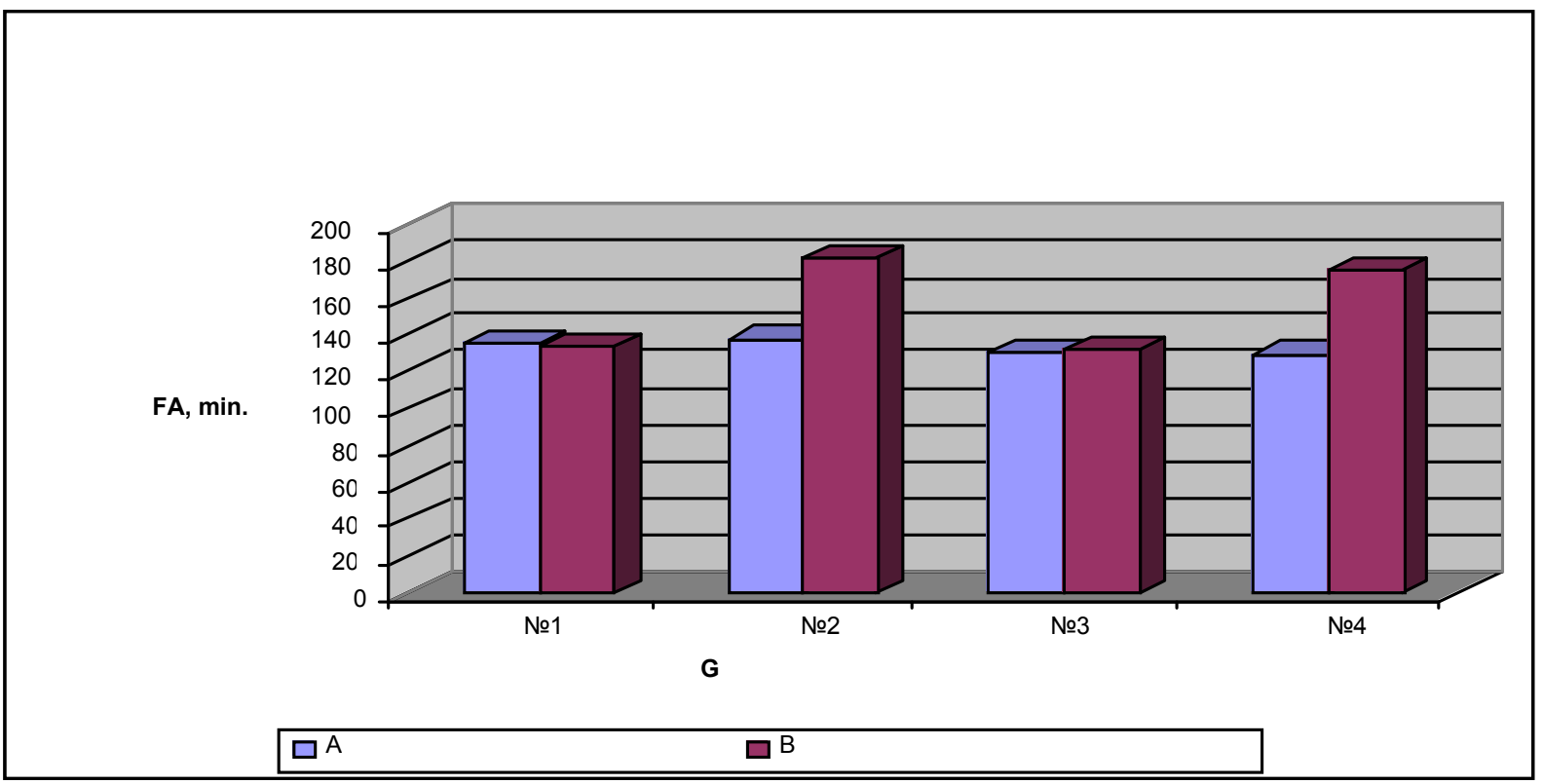

Fig. 1. Dynamics of volume changes of students physical activity per week during researches. FA - the volume of physical activity (minutes), A - the beginning of researches, B - the end of researches, $\mathrm{G}$ - the examined groups.

concerning the weekly volume of physical activity of students of experimental and control groups wasn't significantly differ. At the end of researches was revealed quite significant increase $(\mathrm{P}<0,01)$ in time of physical activity training in students of experimental groups. In males of the experimental group the weekly volume of physical activity increased in $41 \pm 2$ minutes on average, in comparison with data at the beginning of researches. In females of the experimental group this indicator increased in $44 \pm 1$ minutes on average. In students of control groups (males and females) the volume of weekly physical activity was practically at the level of the beginning of researches. Dynamics of volume changes of students' physical activity during researches is presented in figure 1.

\section{Discussion}

The scientific discussion devoted to the most suitable pedagogical models of physical education of youth and students in modern conditions is continued nowadays [31-34]. Experts confirm that the exists structure of medical higher education could cause violation of a healthy lifestyle of future doctors. It is rather difficult to maintain optimum level of physical activity during training of medical students. Busy schedule of training and features of educational activity prevent young people to find time for regular training of physical activity [35]. It should be noted the negative dynamics of decline in level of physical health of medical universities students (in particular Krasnoyarsk State Medical University named after prof. V.F Voino-Yasenetsky) during study period [36]. It was revealed considerable deviations in values of body weight in modern medical students towards increase in body weight and development of obesity [37]. Experts need to pay special attention to this problem and to find effective ways of its decision. Researches demonstrate the ex- istence of essential communication between the level of physical activity and health of the doctor [5] and success of its medical practice [38]. Results of the last researches of level of physical activity of medical students and the practicing doctors in the USA demonstrate: doctors with normal body weight index more likely will achieve increase in level of physical activity of the patients [39]. Polls of patients demonstrate that most of them expect from doctors the health services delivery service in various and emergency situations. Sports activities help medical students to increase the level of the physical and mental training necessary for carrying out various rescue operations [40].

Modern sociological researches demonstrated that a considerable part of students is ready to pay for physical culture extra classes. According to data of S. Kościółek, about $64 \%$ of higher education institutions students of Poland pay for physical culture extra classes [41]. Teachers should support the high level of interest of students to physical culture classes. Scientists confirm that situational interest is the main motivation for students in the field of physical training [42]. It is revealed that positive emotions and increase in popularity among coursemates are the main motives to sports activities and physical activity in students from European countries [22]. The main motives of students to physical activity in Russian higher education institutions are: increase in physical appeal and popularity of different types of physical activity among peers [43].

Scientists confirm that essential changes in the existing programs of physical training of youth are necessary. These changes have to promote formation in young people of the resistant motivational need for the active motion [44]. It should be noted that changes shouldn't include the only simple increase in daily physical activity. Experts 
confirm that the existing education systems don't allow to increase significantly the time of physical training [45], games and sport [46]. It is necessary to develop activities for the increase in motivations to physical activity in free time. Researches demonstrate that regular physical activity promotes decrease of fat tissue content in organism and increase in functionality of cardio respiratory system [47]. The experts emphasized the need for physical activity promotion among medical universities students. In the future (as the practicing doctors) such students could conduct the successful professional practice of patients' consultation concerning physical activity in everyday life [1].

Thus, data of experts' scientific observations are consistent with the direction of authors' researches. Increase in level of physical activity of students is recognized as one of the main directions of high-quality vocational training of future doctors. Various forms of physical education promote the increase in weekly level of physical activity of students. It allows to confirm the achievement of the goal of a research.

\section{Conclusions}

1. In the modern scientific literature, experts express the essential doubt of concerning the level of physical development and health of students of medical schools is expressed. The researches demonstrate that a considerable part of future doctors has no sufficient volume of daily physical activity. The lack of physical activity negatively affects the level of physical development and health of future doctors.

2 . The significant increase in weekly volume of physical activity of medical students is possible by application of various forms of physical culture in the course of physical training. It is revealed the essential increase in time of physical training within a week by students of experimental groups (on average in $42 \pm 1$ minutes). These students attended classes on the basis of personal preferences and in convenient time only.

3. It is revealed significant $(\mathrm{P}<0,01)$ increase in key indicators of physical fitness of experimental groups of students, in comparison with control groups students. Results of tests allow to confirm the higher level of development of the main physical qualities of the students with various forms of physical culture.

4. The obtained data allow to recommend various forms of physical education of youth for counteraction to obesity spread among young people.

\section{Conflict of interests}

The authors state that there is no conflict of interest.

\section{References:}

1. Rao C, Darshan B, Das N. Practice of physical activity among future doctors: A cross sectional analysis. International Journal of Preventive Medicine, 2012; 3(5): 365-369.

2. Molanorouzi K, Khoo S, Morris T. Motives for adult participation in physical activity: type of activity, age, and gender. BMC Public Health, 2015; 15: 66-71. doi:10.1186/ s12889-015-1429-7

3. Sajwani R, Shoukat S, Raza R. Knowledge and practice of healthy lifestyle and dietary habits in medical and nonmedical students of Karachi, Pakistan. The Journal of the Pakistan Medical Association, 2009; 59(9): 650-655.

4. Wattanapisit A, Fungthongcharoen K, Saengow U, Vijitpongjinda S. Physical activity among medical students in Southern Thailand: a mixed methods study. BMJ Open, 2016;6:e013479. doi:10.1136/bmjopen-2016-013479

5. Lobelo F, Duperly J, Frank E. Physical activity habits of doctors and medical students influence their counselling practices. British Journal of Sports Medicine, 2008;43:8992. doi:10.1136/bjsm.2008.055426

6. Al-Drees A, Abdulghani H, Irshad M, Baqays AA, AlZhrani AA, Alshammari SA. Physical activity and academic achievement among the medical students: A cross-sectional study. Medical Teacher, 2016;38:S66-72. doi:10.3109/0142 159X.2016.1142516

7. Keating X, Guan J, Piñero J, et al: A meta-analysis of college students' physical activity behaviors. Journal of American College Health, 2010; 54(2): 116-126. doi:10.3200/ JACH.54.2.116-126

8. Hart M. The importance and elements of healthy nutrition. Advances in Eating Disorders, 2016;4:14-30. doi:10.1080/2 1662630.2015 .1130536

9. Varea V, Underwood M. 'You are just an idiot for not doing any physical activity right now': Pre-service Health and Physical Education teachers' constructions of fatness.
European Physical Educational Review, 2015; 22(4): 465478. doi:10.1177/1356336X15617446

10.Jagiełło M, Iermakov SS, Nowiński M. Differentiation of the somatic composition of students physical education specialising in various sports. Arch Budo Sci Martial Art Extreme Sport, 2017;13:63-70.

11.El-Kassas G, Ziade F. Exploration of the dietary and lifestyle behaviors and weight status and their self-perceptions among health sciences university students in north Lebanon. BioMed Research International, 2016; 2016: 9762396. doi:10.1155/2016/9762396

12.Arlicsson M, Domalewski D, Romild U, et al: Physical activity, health, body mass index, sleeping habits and body complaints in Australian senior high school students. International Journal of Adolescent Medicine and Health, 2008; 20(4): 501-512.

13.Kudryavtsev M, Kramida I, Osipov A. Influence of monitor bad habits on healthy lifestyle of students. Theory and Practice of Physical Culture, 2016; 6: 24-26. (In Russian)

14.Lee K, Cho S. The Korean national curriculum for physical education: a shift from edge to central subject. Physical Education and Sport Pedagogy, 2014, 19(5): 522-532. doi:1 0.1080/17408989.2014.915299

15.Deliens T, Deforche B, Bourdeaudhuij I, et al: Determinants of physical activity and sedentary behaviour in university students: a qualitative study using focus group discussions. BMC Public Health, 2015; 15: 201. doi:10.1186/s12889015-1553-4

16.Osipov AYu, Kudryavtsev MD, Iermakov SS, Jagiello W. Increase in level of special physical fitness of the athletes specialising in different combat sports (judo, sambo, combat sambo) through of crossFit training. Archives of Budo, 2018;14:

17.Majeed F. Association of BMI with diet and physical activity of female medical students at the University of Dammam, 
Kingdom of Saudi Arabia. Journal of Taibah University Medical Sciences, 2015; 10(2): 188-196. doi:10.1016/j. jtumed.2014.11.004

18.Sevindir HK, Yazici C, Setinkaya S. A study on physical exercise habit. Procedia- Social and Behavioral Science, 2014; 152: 648-652. doi:10.1016/j.sbspro.2014.09.257

19.Osipov AY, Kudryavtsev MD, Iermakov SS, Jagiello W. Topics of doctoral and postdoctoral dissertations devoted to judo in period 2000-2016-the overall analysis of works of Russian experts. Archives of Budo, 2017;13:1-10.

20.Shani D, Nimbalkar A, Phatak A, Nimbalkar S. Training in Dietary Practices and Physical Activity to Improve Health among South Asian Medical Students. Advances in Preventive Medicine, 2014;2014:1-5. doi:10.1155/2014/610180

21.Beni S, Fletcher T, Chroinin D. Meaningful Experiences in Physical Education and Youth Sport: A Review of the Literature. Quest, 2017; 69(3): 291-312. doi:10.1080/0033 6297.2016 .1224192

22.Kondric M, Sindik J, Furjan-Mandic G. Participation Motivation and Student's Physical Activity among Sport Students in Three Countries. Journal of Sports Science and Medicine, 2013; 12(1): 10-18.

23.Osipov A, Kudryavtsev M, Fedorova P. Components of positive impact of exposure on university physical culture and sports on students' physical activity. Journal of Physical Education and Sport, 2017; 2: 871-878. doi:10.7752/ jpes.2017.02133

24.Jin A. Physical education curriculum reform in China: a perspective from physical education teachers. Physical Education and Sport Pedagogy, 2013; 18(1): 15-27. doi:10.1 080/17408989.2011.623231

25.Xu J, Gao C, Lee JKW, Zhao J. PM 2.5 : A barrier to fitness and health promotion in China. Journal of Sport and Health Science 2017;6:292-4. doi:10.1016/j.jshs.2017.04.004

26.Sirmpas I, Digelidis N, Watt A. An examination of Greek physical educators' implementation and perceptions of Spectrum teaching styles. European Physical Education Review, 2016; 22(2): 201-214. doi:10.1177/1356336X15598789

27.Roberts S, Reeves M, Ryrie A. The influence of physical activity, sport and exercise motives among UK-based university students. Journal of Further and Higher Education, 2015; 39(4): 598-607.

28. Osipov A, Starova O, Malakhova A. Modernization process of physical education of students in the framework of implementation of the state strategy for the development of physical culture, sport and tourism in the Russian Federation. Journal of Physical Education and Sport, 2016; 4: 12361241. doi:10.7752/jpes.2016.04196

29. Brettschneider A, Schaffrath R, Wiegand S. Development and validation of correction formulas for self-reported height and weight to estimate BMI in adolescents. Results from the KiGGS study. Obesity Facts, 2015; 8: 30-42. doi:10.1159/000375109

30.Peres A, Gabriel K, Nehme E. Measuring the bias, precision, accuracy, and validity of self-reported height and weight in assessing overweight and obesity status among adolescents using a surveillance system. International Journal of Behavioral Nutrition and Physical Activity, 2015; 12(1): S2. doi: $10.1186 / 1479-5868-12-S 1-S 2$

31.Barker DM, Aggerholm K, Standal O, Larsson H. Developing the practising model in physical education: an expository outline focusing on movement capability. Physical Education and Sport Pedagogy, 2018;23:209-21. doi:10.1080/1740898 9.2017.1371685
32.Barker D, Wallhead T, Quennerstedt M. Student learning through interaction in physical education. European Physical Educational Review, 2017; 23(3): 273-278. doi:10.1177/1356336X16640235

33. Wallhead T, Garn A, Vidoni C. Effect of a sport education program on motivation for physical education and leisuretime physical activity. Research Quarterly for Exercise and Sport, 2014; 85(4): 478-487. doi:10.1080/02701367.2014.9 61051

34.Osipov AY, Kudryavtsev MD, Iermakov SS, Jagiello W. Criteria for effective sports selection in judo schools - on example of sportsmanship's progress of young judo athletes in Russian Federation. Archives of Budo, 2017;13:179-186.

35.Al-Asousi M, El-Sabban F. Physical activity among preclinical medical students at the University of Malaya, Malaysia. Journal of Nutritional Health \& Food Science, 2016; 4(2): 1-8. doi:10.15226/jnhfs.2016.00159

36.Artukhov I, Kaskaeva D. Health status assessment of the higher educational institutions students in Krasnoyarsk. Siberian Medical Review, 2014; 6(90): 61-64. (In Russian)

37.Peshkov M, Sharaykina E. Body mass index in students: the present state of the problem. Siberian Medical Review, 2014; 4(88): 49-56. (In Russian)

38.Duperly J, Lobelo F, Segura C, et al: The association between Colombian medical students' healthy personal habits and a positive attitude toward preventive counseling: crosssectional analyses. BMC Public Health, 2009; 9: 218-224. doi:10.1186/1471-2458-9-218

39.Stanford FC, Durkin MW, Stallworth JR, Powell CK, Poston MB, Blair SN. Factors that Influence Physicians' and Medical Students' Confidence in Counseling Patients About Physical Activity. The Journal of Primary Prevention, 2014;35:193201. doi:10.1007/s10935-014-0345-4

40.Kałużny R, Klimczak J. Declared by medical students actions towards of people in emergency situations - mixed assessments as a basis for analysis of simulation studies. Archives of Budo, 2017; 13: 323-333.

41.Kościółek S. Determinants of Demand for Physical Activity among Students in Krakow. Physical Culture and Sport. Studies and Research, 2017; 74(1): 34-42. doi:10.1515/ pcssr-2017-0009

42.Roure C, Kermarrek G, Pasco D. Effects of situational interest dimensions on students' learning strategies in physical education. European Physical Educational Review, 2017. doi:10.1177/1356336X17732964

43.Petrova M, Pronina E, Baron I. The attitude of the students of Krasnoyarsk State Medical University named after professor V.F. Voino-Yasenetsky to physical activity. Siberian Medical Review, 2016; 2(98): 88-92. (In Russian)

44. Bott T, Mitchell M. Battling obesity with quality elementary physical education: From exposure to competence. Journal of Physical Education, Recreation \& Dance, 2015; 86(6): 24-28. doi:10.1080/07303084.2015.1053637

45.Gråstén A. School-based physical activity interventions for children and youth: Keys for success. Journal of Sport and Health Science, 2017; 6(3): 290-291. doi:10.1016/j. jshs.2017.03.001

46. Bichescu A. Leisure time sport activities of the students at Resita University. Procedia - Social and Behavioral Sciences, 2014; 117: 735-740. doi:10.1016/j.sbspro.2014.02.291

47.Kuzhuget A, Rubanovich V, Aizman R. Morphological and functional development of students going for different sport activities. Siberian Medical Review, 2011; 2(68): 57-61. (In Russian) 
Information about the authors:

Osipov A.Yu.; http://orcid.org/0000-0002-2277-4467; Siberian Federal University; 79 Svobodny pr., Krasnoyarsk, 660041, Russia.; Professor V.F. Voino-Yasenetsky Krasnoyarsk State Medical University; P. Zeleznyak, 1, Krasnoyarsk, 660022, Russia.; The Siberian Law Institute of the Ministry of Internal Affair of Russia.; Rokossovskia str., 20, Krasnoyarsk, 660131, Russia.

Kudryavtsev M. D.; (Corresponding author); http://orcid.org/0000-0002-2432-1699; kumid@yandex.ru; Siberian Federal University; 79 Svobodny pr., Krasnoyarsk, 660041, Russia.; Reshetnev Siberian State University of Science and Technology; Office A-406, 31 Krasnoyarsky Rabochy Av., 660014, Krasnoyarsk, Russia.; Krasnoyarsk State Pedagogical University of V.P. Astafyev; Ada Lebedeva Street, 89, Krasnoyarsk, 660049, Russia.; The Siberian Law Institute of the Ministry of Internal Affair of Russia; Rokossovskia str. 20, Krasnoyarsk, 660131, Russia.

Markov K.K.; http://orcid.org/0000-0003-1893-5907; National Research Irkutsk State Technical University; Lermontov 83, Irkutsk, 664074, Russia.

Kuzmin V.A.; http://orcid.org/0000-0002-4190-1628; Siberian Federal University, Siberian State Aerospace University; 79 Svobodny pr., Krasnoyarsk, 660041, Russia.

Nikolaeva O.O.; http://orcid.org/0000-0002-8564-7174; Siberian Federal University; Svobodny Avenue, 79 Krasnoyarsk, 660041, Krasnoyarsk, Russia.; Zemba E.A.; http://orcid.org/0000-0003-1656-3791; zembaelena@rambler.ru; Reshetnev Siberian State University of Science and Technology; Office A-406, 31, Krasnoyarsky Rabochy Av., 660014, Krasnoyarsk, Russia.

Yanova M.G.; http://orcid.org/0000-0003-4262-7015; Krasnoyarsk State Pedagogical University of V.P. Astafyev; Ada Lebedeva Street, 89, Krasnoyarsk, 660049, Russia.

Cite this article as: Osipov A.Yu., Kudryavtsev M.D., Markov KK, Kuzmin VA, Nikolaeva OO, Zemba EA, Yanova MG. Application of various forms of physical education as a factor of increase in the level of physical activity of medical students. Physical education of students, 2018;22(3):139-145. doi:10.15561/20755279.2018.0305

The electronic version of this article is the complete one and can be found online at: http:/www.sportedu.org.ua/index.php/PES/issue/archive

This is an Open Access article distributed under the terms of the Creative Commons Attribution License, which permits unrestricted use, distribution, and reproduction in any medium, provided the original work is properly cited (http://creativecommons.org/licenses/by/4.0/deed.en).

Received: 05.01.2018

Accepted: 01.02.2018; Published: 27.06.2018 